\title{
Community study of tubeworm-associated epizooic meiobenthos from deep-sea cold seeps and hot vents
}

\author{
Renate Degen $^{1,2, *}$, Laura Riavitz ${ }^{1}$, Sabine Gollner ${ }^{1,3}$, Ann Vanreusel $^{4}$, \\ Christoph Plum ${ }^{5}$, Monika Bright ${ }^{1}$ \\ ${ }^{1}$ University of Vienna, Department of Marine Biology, 1090 Vienna, Austria \\ ${ }^{2}$ Alfred Wegener Institute for Polar and Marine Research, 27570 Bremerhaven, Germany \\ ${ }^{3}$ Deutsches Zentrum für Marine Biodiversitätsforschung, Forschungsinstitut Senckenberg, 26382 Wilhelmshaven, Germany \\ ${ }^{4}$ University of Ghent, Marine Biology Research Group, 9000 Ghent, Belgium \\ ${ }^{5}$ University of Oldenburg, Institute for Chemistry and Biology of the Marine Environment, 26382 Wilhelmshaven, Germany
}

\begin{abstract}
The permanent metazoan meiofauna associated with vestimentiferan tubeworm aggregations from hydrocarbon seeps of the upper Louisiana slope in the Green Canyon ( $550 \mathrm{~m})$ and the lower slope in Atwater Valley ( $2200 \mathrm{~m}$ ) of the Gulf of Mexico was characterized. Meiofauna abundance, diversity, and community composition at genus level were compared between these seep sites, and with those of tubeworms from hydrothermal vents of the East Pacific Rise (Gollner et al. 2007; Mar Ecol Prog Ser 337:39-49). The abundance was not significantly different between the 2 seep sites, and was also similar to those found at vents. A total of 150 meiobenthic genera were identified from the cold seep sites. While no significant difference in univariate measurements of diversity was detected, a shift in community composition between the shallow and the deep seep site was found. The hot vent communities included a total of only 17 genera and the diversity measurements were significantly lower at vents than at seeps. Also, Bray-Curtis dissimilarity was $97 \%$ between the meiobenthic communities from seeps and vents. The genera richness was negatively correlated with maximum temperature and maximum sulfide concentration, and positively correlated with minimum $\mathrm{pH}$ value. We conclude that the harsh conditions tubeworms experience at vents compared to the moderate conditions at cold seeps, as well as the longevity of cold seeps surrounded by sedimented deep-sea plains but short-lived vents on basaltic mid-ocean ridges, might explain the contrasting diversity patterns.
\end{abstract}

KEY WORDS: Meiobenthos - Meiofauna $\cdot$ Cold seep $\cdot$ Hydrothermal vent $\cdot$ Community study $\cdot$ Biodiversity $\cdot$ Vestimentiferans $\cdot$ Gulf of Mexico

Resale or republication not permitted without written consent of the publisher

\section{INTRODUCTION}

Following Dayton (1972), a foundation species is described as 'a single species that defines much of the structure of a community by creating locally stable conditions for other species, and by modulating and stabilizing fundamental ecosystem processes' (p. 85). By providing protection from environmental stress and/or predation, foundation species can often have a positive effect on local species richness (see Bruno \& Bertness 2001). The term has been used for a variety of marine organisms shaping ecosystems such as coral reefs (Bruno et al. 2003), kelp forests (Graham 2004), mussel beds (Cordes et al. 2010), and also for vestimentiferan tubeworm aggregations from the chemosynthetic deep-sea environments such as cold seeps (Cordes et al. 2005b, 2010) and hydrothermal vents (Gollner et al. 2007, 2010a). The tubes of 
vestimentiferans (Polychaeta, Siboglinidae) create complex secondary structures that serve as a living space for a variety of associated species (Bright \& Lallier 2010).

Symbiont-housing foundation species from cold seeps of the Gulf of Mexico have been studied extensively (Levin 2005, Fisher et al. 2007, Cordes et al. 2009). The cold seep sites on the upper Louisiana slope $(<1000 \mathrm{~m}$ depth) in the Gulf of Mexico are colonized by 3 species of vestimentiferan tubeworms: Lamellibrachia luymesi van der Land \& Nørrevang, 1975; Seepiophila jonesi Gardiner, McMullin \& Fischer, 2001; and a still undescribed species of escarpids (McMullin 2003). On the lower slope (>1000 m depth), Escarpia laminata Jones, 1985 and 2 still undescribed species of lamellibrachids (see Cordes et al. 2009) are found.

Hundreds to thousands of individuals of Seepiophila jonesi co-occurring with Lamellibrachia luymesi form bush-like aggregations several meters in diameter and sometimes over $2 \mathrm{~m}$ in height on the upper slope (Bergquist et al. 2002). Conservative age estimates of L. luymesi are well over 100 years, with the upper limit of age still unknown (Fisher et al. 1997, Bergquist et al. 2000, Cordes et al. 2005b). Vestimentiferan tubeworms with sulfide-oxidizing symbionts settle on a seepage site as soon as sulfide at the substrate/water interface and suitable carbonate substrata within the otherwise sedimented deep-sea plains are present (Bergquist et al. 2002, 2003a). Fluid flow is continuous and may last over a thousand years or more (Levin 2005), but tubeworms reduce the amount of sulfide within or around an aggregation (Cordes et al. 2009); thus, a relatively stable and stressless environment for associated organisms is created. In general, seep tubeworm aggregations are characterized by ambient deep-sea temperatures, ambient $\mathrm{pH}$, and very low sulfide concentrations (i.e. $4 \mu \mathrm{M} \mathrm{kg}^{-1}$ ) (Freytag et al. 2001, Bergquist et al. 2003b, Cordes et al. 2005a).

Stability favored the evolution of longevity in these seep tubeworm species (Cordes et al. 2007), in contrast to the relatively short-lived and fast growing vestimentiferans from the highly disturbed and stressful hydrothermal vents (Lutz et al. 1994). While cold seeps are located within soft sedimented plains on active and passive continental margins and can last over hundreds of years, deep-sea vents are mostly found on basaltic mid-ocean ridges and back spreading centers and, in general, exist only for a few years to some decades (Van Dover \& Trask 2000). The vent foundation species Riftia pachyptila Jones,
1981 and organisms associated with these tubeworms have to deal with highly variable physicochemical conditions such as high and varying temperatures (i.e. peaks of $\max .54^{\circ} \mathrm{C}$, changes within seconds of up to $15^{\circ} \mathrm{C}$ ), low $\mathrm{pH}$ gradients (i.e. $\mathrm{pH} 4$ ), high levels of sulfide (i.e. $280 \mu \mathrm{M} \mathrm{kg}^{-1}$ ), intermittent availability of oxygen and changing vent fluid composition and/or flux (Le Bris et al. 2006, Bright \& Lallier 2010, Gollner et al. 2010a).

Meiobenthic communities play a major role in reduced ecosystems, as they form an important link between bacteria and larger fauna (Giere 2009). Although their importance is commonly acknowledged, such studies from cold seeps are scarce. These studies mainly focus on the infaunal meiobenthos from seep sediments in terms of abundance, biomass, and composition of higher taxa only or concentrate on nematode species diversity, the most prominent meiobenthic phylum (see Bright et al. 2010). Although species diversity studies from epizooic meiofaunal communities associated with hydrothermal vent tubeworms have been recently published (Gollner et al. 2007, 2010a), only one study describes the epizooic meiobenthos associated with tubeworms and mussels at seeps, focusing on abundance and higher taxonomic composition (Bright et al. 2010).

Low abundances were reported for seep and hydrothermal vent epizooic meiofauna, compared to the background deep-sea meiofauna (Bright et al. 2010, Gollner et al. 2010a). Contrasting with the theory of habitat provision (Bruno \& Bertness 2001), epizooic meiofauna associated with tubeworms exhibited lower species diversity than meiofauna from nearby bare basalt areas that harbored no foundation fauna and was, thus, less heterogeneous (Gollner et al. 2010a). However, it has to be noted that stress through toxic and hot hydrothermal vent fluid emissions was high at tubeworm sites, but absent on the bare basalt (Gollner et al. 2010a). From cold seeps, no data are yet available on the total meiofauna communities at the genus- or species level. The nematode fauna from highly sulfidic and oxygen-depleted seep sediments underneath bacterial mats was found significantly less diverse than adjacent deep-sea sediments. In contrast, the diversity of nematodes from well-oxygenated surface sediments from seep siboglinid fields was similar to the surrounding sediments (Van Gaever et al. 2010, Vanreusel et al. 2010a).

In this study, we investigated the abundance, diversity, and genera composition of epizooic, permanent, metazoan meiobenthos associated with ves- 
timentiferan tubeworm aggregations from 2 different cold seep sites from the upper and lower Louisiana slope of the Gulf of Mexico. Further, the results of this study allow, for the first time, a detailed comparison of epizooic meiobenthic communities from 2 deepsea chemosynthesis-based ecosystems, the cold seeps and hydrothermal vents. The questions addressed were: (1) Are seep meiofauna communities in the Gulf of Mexico, which are separated in geographic distance and depth, similar in their abundance, diversity, and community composition? (2) Do meiofauna communities from cold seeps and hydrothermal vents show differences in their abundance, diversity, and composition?

\section{MATERIALS AND METHODS}

\section{Collection sites}

Four vestimentiferan aggregations from the Green Canyon (GC) seep site were collected during a cruise with the RV Seward Johnson II and the Johnson SeaLink I and II submersibles on the upper Louisiana slope of the Gulf of Mexico in 2003. Two collections were sampled from GC $232\left(27^{\circ} 44.5^{\prime} \mathrm{N}, 91^{\circ} 19.1^{\prime} \mathrm{W}\right)$ and GC $234\left(27^{\circ} 44.7^{\prime} \mathrm{N}, 91^{\circ} 13.3^{\prime} \mathrm{W}\right)$, which were about $10 \mathrm{~km}$ apart and between 538 to $571 \mathrm{~m}$ deep (Cordes et al. 2005a, 2006). They were similar in their geophysical and geochemical conditions (maximum temperature, $T_{\max } 4^{\circ} \mathrm{C}$; min. $\mathrm{pH} 7.7$; max. sulfide concentration $1 \mu \mathrm{M})$. Three collections were obtained from Atwater Valley (AT 340) (AT 1: $27^{\circ} 38.8^{\prime} \mathrm{N}, 88^{\circ}$ $22.4^{\prime} \mathrm{W}_{\text {; }}$ AT $2: 27^{\circ} 38.7^{\prime} \mathrm{N}, 88^{\circ} 21.8^{\prime} \mathrm{W}$; AT 3: $27^{\circ} 38.7^{\prime}$ $\mathrm{N}, 88^{\circ} 21.9^{\prime} \mathrm{W}$ ), and previous abundance data published by Bright et al. (2010) was included. These collections were sampled during cruises with the RV 'Atlantis' and DSV 'Alvin' in 2006, and the NOAA RV 'Ronald Brown' and ROV 'Jason' in 2007, at depths from 2175 to $2192 \mathrm{~m}\left(T_{\max } 2^{\circ} \mathrm{C}_{i}\right.$ min. $\mathrm{pH} 7.7$; max. sulfide concentration $1 \mu \mathrm{M})$.

For comparisons between cold seep and hydrothermal vent meiobenthos, we used 6 vestimentiferan aggregations from the East Pacific Rise (EPR) $9^{\circ} 50^{\prime} \mathrm{N}$ region, previously published by Gollner et al. (2007). They were collected during cruises at Tica (TC 1-3: $9^{\circ} 50.4^{\prime} \mathrm{N}, 104^{\circ} 17.5^{\prime} \mathrm{W}$ ) and Riftia Field (RF 1-3: $9^{\circ} 50.7^{\prime} \mathrm{N}, 104^{\circ} 17.5^{\prime} \mathrm{W}$ ) at $2500 \mathrm{~m}$ depth in 2001 and 2002 (Tica: $T_{\max } 18^{\circ} \mathrm{C}$, max. sulfide concentration $176 \mu \mathrm{M}$, min. $\mathrm{pH} 7$; Riftia Field: $T_{\max } 23^{\circ} \mathrm{C}$, max. sulfide concentration $35 \mu \mathrm{M}$, min. pH 5; for details see Govenar et al. 2005, Le Bris et al. 2006, Gollner et al. 2007).

\section{Sample collections and processing}

All vestimentiferan aggregations were obtained using the Bushmaster Jr. collection device, with a maximum surface area of $2800 \mathrm{~cm}^{2}$ (see Bergquist et al. 2003a, Cordes et al. 2005b for further details). Whereas for seep samples, this maximum surface area was obtained and used for calculations of total abundances; for the vent samples, a smaller surface area between 300 and $1300 \mathrm{~cm}^{2}$ was obtained and total abundances were calculated accordingly (see Gollner et al. 2007).

On board, seep samples were rinsed into a tub with cold, $32 \mu \mathrm{m}$ filtered seawater (see Bergquist et al. 2003a, Cordes et al. 2005b). The tubeworms were rinsed, identified, counted, and measured onboard. The GC samples were composed of Lamellibrachia luymesi and Seepiophila jonesi (percentages $L$. luymesi: GC 1a 69.1\%, GC 1b 48.7\%, GC 2a 61.2\%, GC 2b $76 \%$ ) (Cordes et al. 2005b). The samples AT 1 and AT 2 consisted exclusively of Escarpia laminata and samples AT 3 included Lamellibrachia sp. (4.5\%) in addition to E. laminata (94. 5\%). The length of tubeworms was measured and standardized to the posterior outer tube diameter (see Bergquist et al. 2000, Cordes et al. 2005b), and surface area was calculated as for a cone frustum (see Bergquist et al. 2003a, Cordes et al. 2005b). The remaining content in the tub was sieved consecutively through $2 \mathrm{~mm}$, $1 \mathrm{~mm}$, and $32 \mu \mathrm{m}$ meshes to separate the macro(>1 mm sieve size) from the meiofauna ( $>32 \mu \mathrm{m}$ $<1 \mathrm{~mm}$ size). The macrofauna was identified on board the ship and is published in Cordes et al. (2005b) and Cordes et al. (2010). The retained meiofauna was fixed and stored in $4 \%$ buffered formalin.

The vent samples were treated slightly differently. Briefly, tubes were washed with filtered seawater into a large container. The rinsed Riftia pachyptila tubeworms were picked out and the length and the anterior diameter of each tube were measured in order to obtain the tube surface area (Govenar et al. 2005). The remaining samples were sieved through $1 \mathrm{~mm}$ and $63 \mu \mathrm{m}$ meshes to separate the meiofauna from the macrofauna. The macrofauna was published by Govenar et al. (2005). Meiofauna samples were fixed in $4 \%$ buffered formalin for $24 \mathrm{~h}$ and stored in $70 \%$ Ethanol (Gollner et al. 2007). Later, additional qualitative tubeworm samples were taken in the same area in order to check for the presence of fauna on a $32 \mu \mathrm{m}$ sieve. No animals were found (see Gollner et al. 2010a).

Sulfide concentration at the cold seep sites was measured using the enzymatic assay of Singh et al. 
(1993) as modified by Freytag et al. (2001) (for details see Cordes et al. 2005b) and at hydrothermal vent sites the in situ flow analyzer, 'ALCHIMIST' was used (for details see Le Bris et al. 2006).

\section{Identification and quantification}

In the lab, meiofauna was extracted from the sediment using a density centrifugation technique with a medium consisting of a Silicapolymer (Fa. Levasil ${ }^{\circledR}$ ) mixed with Kaolin (McIntyre \& Warwick 1984, VeitKöhler et al. 2008). The meiofauna samples AT 2, AT 3, TC 1-3 and RF 1-3 were counted entirely. For the samples GC 1-4 and AT 1, subsamples were taken due to the large sizes of the samples, and the total abundance was finally extrapolated to the original sample volume All animals belonging to the meiobenthos (permanent and temporary) were sorted, counted, and identified (to the lowest taxon level possible) using a dissecting microscope. The temporary meiobenthos, as well as protists, and crustacean nauplii were also recorded, but are not included in this study.

If present in the sample, 300 ind. of each higher taxon were picked out for identification to the genus level; the remaining individuals were only counted. Nematodes were mounted on slides using glycerine (Higgins \& Thiel 1988) and identified following mainly Platt \& Warwick (1983), Platt \& Warwick (1988) and Warwick et al. (1998). In the case of seeps, all specimens of other taxa were sent to experts for further identification. C. Plum identified all copepods, M. Bright identified kinorhynchs, L. S. Kornicker and R. F. Maddocks identified ostracods, K. Larsen identified the tanaids, and I. Bartsch identified the halacarids. The vent meiofauna community from the EPR (Gollner et al. 2007) was identified to species level, and included foraminiferans. In order to make the seep and vent communities comparable, the abundance data from the EPR were recalculated without foraminiferans and to the genus level. The abundance was standardized to $10 \mathrm{~cm}^{2}$ sample area.

\section{Diversity indices and statistical analyses}

For description of the diversity the genus richness $(G)$ and the diversity indices Shannon diversity $\left(H^{\prime}\right)$, Pielou's evenness $\left(J^{\prime}\right)$, and estimated genus richness (EG(n)) were calculated using Primer Version 6 package (Clarke \& Gorley 2006). Cumulative $k$-dominance curves were generated to determine the dominance of the most common genera.
Similarity and differences in the community structure between the samples were analyzed by multidimensional scaling (MDS), similarity percentage (SIMPER), and analysis of similarity (ANOSIM) using again Primer Version 6. Similarity between genera distributions was assessed by constructing cluster dendrograms from Bray-Curtis similarity values (Bray \& Curtis 1957). The abundances of genera were standardized beforehand and square-root transformed to down-weigh the importance of very abundant genera without losing the influence of rarer genera (Clarke \& Gorley 2006). Primer Version 6 was also used to test the impact of abiotic factors on the community composition with the BIO-ENV procedure.

Student's $t$-tests were carried out using STATISTICA to test for differences in abundance (squareroot transformed), relative abundance of nematodes and copepods (arcsin transformed), EG(n) (squareroot transformed), sediment volume (ln transformed), tube surface area (ln transformed), and the diversity indices $H^{\prime}$ and $J^{\prime}$ (no transformation) between GC and AV samples as well as between seep and vent samples. In addition, bootstrapping was used because of the low number of samples and high variances (10000 resamplings each, $t$-test, 2-sided test, routine 'FTBOOT' from the package 'computer intensive statistics', Nemeschkal 1999). Significance levels were classical Bonferroni corrected $\left(\mathrm{p}=\alpha / \mathrm{n}_{\text {; }}\right.$ $\alpha=0.05)$. Significance of correlations was tested among abundance, relative abundance, EG(n), sediment volume, abiotic factors, and tube surface area using Pearson's r ( $F$-value and $t$-value calculations by STATISTICA).

\section{RESULTS}

\section{Seep abundances}

More than 800000 epizooic, meiobenthic individuals were collected from the 4 Green Canyon samples (GC $1 \mathrm{a}, \mathrm{b}, \mathrm{GC} 2 \mathrm{a}, \mathrm{b})$ and the 3 Atwater Valley samples (AT 1-3), with a total surface area of $19600 \mathrm{~cm}^{2}$ sampled (Table 1, see also Bright et al. 2010 for data on 2 samples of AT included in this study). Standardized to $10 \mathrm{~cm}^{2}$, the number of animals ranged between 171 and 1817 ind. $10 \mathrm{~cm}^{-2}$ at GC and between 7 and 448 ind. $10 \mathrm{~cm}^{-2}$ at AT (Table 1). No significant differences in abundance between sites were detected (bootstrapping, $p=0.19$ ). Also when standardized to the tube surface area of foundation species, no differences were found (bootstrapping, $\mathrm{p}=0.43$ ). 
Table 1. Environmental characteristics and abundances (total and standardized to $10 \mathrm{~cm}^{2}$ ) for the Green Canyon seeps (GC), the Atwater Valley seeps (AT) and the vent sites Tica (TC) and Riftia Field (RF). (-) None observed

\begin{tabular}{|c|c|c|c|c|c|c|c|c|c|c|c|}
\hline & \multicolumn{3}{|c|}{ — Environmental characteristics — } & \multicolumn{5}{|c|}{ - Abundance (no. individuals) } & \multirow[b]{2}{*}{$\begin{array}{c}\text { Kino- } \\
\text { rhyncha }\end{array}$} & \multirow[b]{2}{*}{ Isopoda } & \multirow[b]{2}{*}{ Total } \\
\hline & $\begin{array}{c}\text { Sample } \\
\text { area } \\
\left(\mathrm{cm}^{2}\right)\end{array}$ & $\begin{array}{c}\text { Tube } \\
\text { surface } \\
\text { area }\left(\mathrm{cm}^{2}\right)\end{array}$ & $\begin{array}{l}\text { Sediment } \\
(\mathrm{ml})\end{array}$ & Nematoda & Copepoda & Ostracoda & $\begin{array}{l}\text { Tanaid- } \\
\text { aceae }\end{array}$ & $\begin{array}{l}\text { Hala- } \\
\text { carida }\end{array}$ & & & \\
\hline \multicolumn{12}{|l|}{ Total } \\
\hline GC 1a & 2800 & 8990.00 & 4937.64 & 448619.97 & 56782.87 & 2645.16 & 705.38 & - & - & - & 508753.39 \\
\hline $\mathrm{GC} 1 \mathrm{~b}$ & 2800 & 5910.00 & 4565.99 & 40467.21 & 5998.46 & 537.18 & 805.76 & 89.53 & - & - & 47898.14 \\
\hline GC 2a & 2800 & 9850.00 & 5671.22 & 36394.46 & 26728.72 & 1479.45 & 295.89 & - & - & - & 64898.52 \\
\hline GC $2 b$ & 2800 & 600.00 & 4632.90 & 47992.07 & 1663.09 & - & - & - & - & - & 49655.16 \\
\hline AT 1 & 2800 & 12740 & 7500.00 & 103617.51 & 20460.83 & 1002.00 & 345.62 & - & - & - & 125425.96 \\
\hline AT 2 & 2800 & 16870 & 16.00 & 1547.00 & 755.00 & 9.00 & 1.00 & 6.00 & - & - & 2318.00 \\
\hline AT 3 & 2800 & 8590 & 301.63 & 1132.00 & 722.00 & 15.00 & 6.00 & 2.00 & 1.00 & 1.00 & 1879.00 \\
\hline TC 1 & 600 & 52300 & 88.00 & 951.00 & 217.00 & - & - & - & - & - & 1168.00 \\
\hline TC 2 & 300 & 65500 & 165.00 & 28369.00 & 807.00 & 4.00 & - & - & - & - & 29180.00 \\
\hline TC 3 & 700 & 38000 & 133.00 & 3237.00 & 983.00 & 1.00 & - & - & - & - & 4221.00 \\
\hline RF 1 & 1300 & 9600 & 40.00 & 20.00 & 25.00 & - & - & - & - & - & 45.00 \\
\hline RF 2 & 600 & 18300 & 37.00 & 11.00 & 48.00 & - & - & - & - & - & 59.00 \\
\hline RF 3 & 800 & 26600 & 85.00 & 573.00 & 342.00 & 15.00 & - & - & - & - & 930.00 \\
\hline \multicolumn{12}{|c|}{ Standardized to $10 \mathrm{~cm}^{-2}$} \\
\hline GC 1a & & 32.11 & 17.63 & 1602.21 & 202.80 & 9.45 & 2.52 & - & - & - & 1816.98 \\
\hline $\mathrm{GC} 1 \mathrm{~b}$ & & 21.11 & 16.31 & 144.53 & 21.42 & 1.92 & 2.88 & 0.32 & - & - & 171.06 \\
\hline GC 2a & & 35.18 & 20.25 & 129.98 & 95.46 & 5.28 & 1.06 & - & - & - & 231.78 \\
\hline $\mathrm{GC} 2 \mathrm{~b}$ & & 2.14 & 16.55 & 171.40 & 5.94 & - & - & - & - & - & 177.34 \\
\hline AT 1 & & 45.5 & 26.79 & 370.06 & 73.07 & 3.58 & 1.23 & - & - & - & 447.95 \\
\hline AT 2 & & 60.25 & 0.06 & 5.53 & 2.70 & 0.03 & - & 0.02 & - & - & 8.28 \\
\hline AT 3 & & 30.68 & 1.08 & 4.04 & 2.58 & 0.05 & 0.02 & 0.01 & - & - & 6.71 \\
\hline TC 1 & & 872 & 1.47 & 15.85 & 3.62 & - & - & - & - & - & 19.47 \\
\hline TC 2 & & 2183 & 5.50 & 945.63 & 26.90 & 0.13 & - & - & - & - & 972.66 \\
\hline TC 3 & & 543 & 1.90 & 46.24 & 14.04 & 0.01 & - & - & - & - & 60.29 \\
\hline RF 1 & & 74 & 0.31 & 0.15 & 0.19 & - & - & - & - & - & 0.34 \\
\hline RF 2 & & 305 & 0.62 & 0.18 & 0.80 & - & - & - & - & - & 0.98 \\
\hline RF 3 & & 333 & 1.06 & 7.16 & 4.27 & 0.19 & - & - & - & - & 11.62 \\
\hline
\end{tabular}

A total of 7 higher taxa were identified, but only 2 of them, nematodes and copepods, were present in all samples. Ostracods and tanaids were absent in GC $2 \mathrm{~b}$, halacarids were only detected in low numbers in samples GC 1b, AT2, AT3. Kinorhynchs and isopods were only found in AT 3. Nematodes were always the most abundant taxon, with ranges from 4 to 1602 ind. $10 \mathrm{~cm}^{-2}$. The next prevalent taxon was the copepods, with abundances between 3 and 203 ind. $10 \mathrm{~cm}^{-2}$. Where present, the numbers of ostracods ranged from $<1$ to 9 ind. $10 \mathrm{~cm}^{-2}$, tanaids from 1 to 3 ind. $10 \mathrm{~cm}^{-2}$, and halacarids, kinorhynchs, and isopods had $<1$ ind. $10 \mathrm{~cm}^{-2}$.

The relative abundances of nematodes and copepods were highly variable and no significant differences were detected between GC and AT. Nematodes contributed $>56 \%$ and up to $93 \%$ to the total community, while copepods ranged between 3 and $41 \%$. The relative abundance of other higher taxa ranged from $<1$ to $2 \%$ at $\mathrm{GC}$, but were around or below $<1 \%$ at AT (Fig. 1).

\section{Seep diversity at genus level}

A total of 150 meiobenthic genera were identified from all samples. At GC, 93 genera were found, whereas AT samples contained 119 genera (Table 2). At GC, EG(n) was between 25 and 59 genera, while at AT between 44 and 77 genera were found. Accordingly, the number of expected genera EG(100) was between 16 and 31 at GC, and between 25 and 41 at AT. Both these univariate measures of diversity were not significantly different between sites (bootstrapping, $H^{\prime}, \mathrm{p}=0.57$; $\left.\mathrm{EG}(100), \mathrm{p}=0.36\right)$. GC and AT samples had 53 genera in common (26 nematodes, 22 copepods, 3 ostracods, 1 halacarid, and 1 tanaid). At GC, 42 genera (29 nematodes, 6 copepods, 6 ostracods and 1 tanaid) and at AT, 57 genera (32 nematodes, 21 copepods, 2 ostracods, 1 isopod, 1 kinoryhnch) were exclusively found, respectively. The $J^{\prime}$ values were similar between sites (bootstrapping, $\mathrm{p}=0.98$ ) and were between 0.59 and 0.84 (Table 2). The cumulative $k$-dominance curves show 


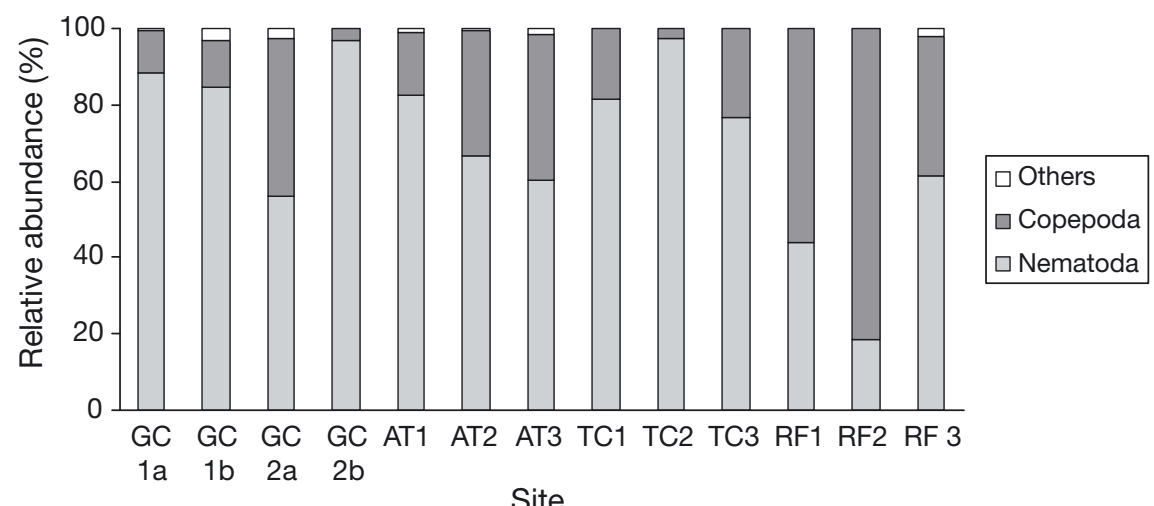

Fig. 1. Relative abundance of Nematoda, Copepoda and other taxa (including Ostracoda, Tanaidacea, Halacarida, Kinorhyncha and Isopoda) from the cold seep sites Green Canyon (GC) and Atwater Valley (AT) and the hot vent sites Tica (TC) and Riftia Field (RF)

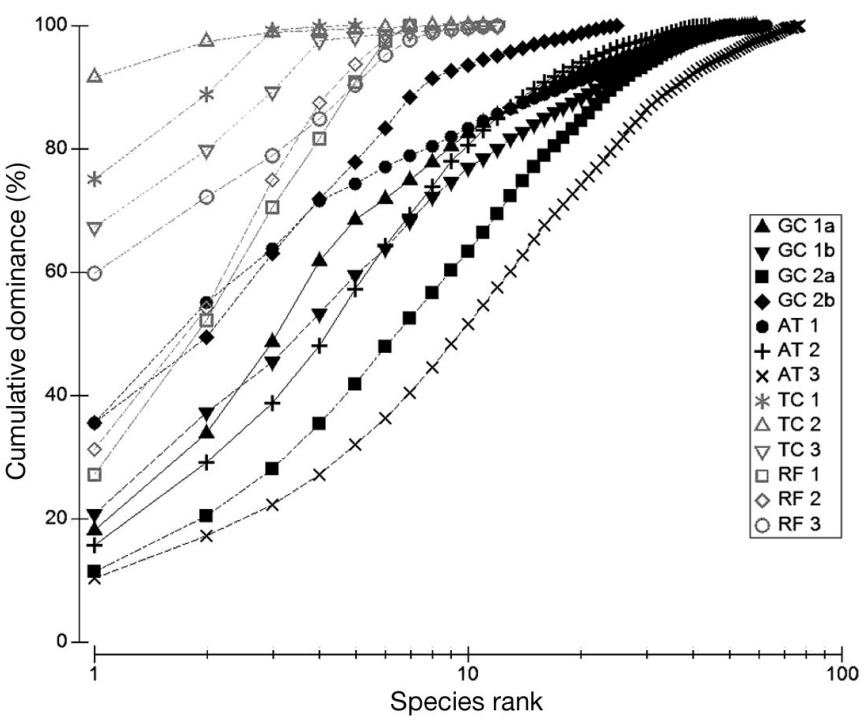

Fig. 2. Cumulative $k$-dominance curves of the cold seep samples from Green Canyon (GC) and Atwater Valley (AT) and the hot vent samples from Tica (TC) and Riftia Field (RF) with relative abundance of genera being plotted against genus ranks

Table 2. Genus richness $(G)$, Shannon diversity $\left(H^{\prime}\right)$, Pielou's evenness $\left(J^{\prime}\right)$ and estimated genus richness $(\mathrm{EG}(100))$ of the seep samples from Green Canyon (GC) and Atwater Valley (AT) and the vent samples Tica (TC) and Riftia Field (RF)

\begin{tabular}{|lrccc|}
\hline Sample & $G$ & $J^{\prime}$ & $H^{\prime}$ & EG(100) \\
\hline GC 1a & 59 & 0.67 & 2.73 & 30.15 \\
GC 1b & 50 & 0.75 & 2.92 & 30.61 \\
GC 2a & 50 & 0.84 & 3.29 & 30.83 \\
GC 2b & 25 & 0.67 & 2.15 & 16.01 \\
AT 1 & 63 & 0.59 & 2.46 & 32.91 \\
AT 2 & 44 & 0.75 & 2.84 & 24.96 \\
AT 3 & 77 & 0.84 & 3.66 & 40.71 \\
TC 1 & 5 & 0.47 & 0.76 & 4.06 \\
TC 2 & 11 & 0.16 & 0.37 & 8.72 \\
TC 3 & 12 & 0.44 & 1.09 & 7.74 \\
RF 1 & 7 & 0.90 & 1.75 & 7.00 \\
RF 2 & 7 & 0.86 & 1.68 & 7.00 \\
RF 3 & 12 & 0.57 & 1.43 & 9.17 \\
\hline
\end{tabular}

that the communities of all samples were quite evenly distributed (Fig. 2). The $H^{\prime}$ values ranged from 2.15 to 3.29 at GC and between 2.46 and 3.66 at $\mathrm{AT}$, and were similar between sites (bootstrapping, $H^{\prime}, \mathrm{p}=0.57$ ) (Table 2).

The relative abundances of all genera are shown in Table S1 in the supplement at www.int-res.com/ articles/suppl/m468p135_supp.pdf. At GC 1a, the nematode Sabatieria showed the highest relative abundance of $17 \%$, followed by the nematodes Desmodora (15\%) and Dorylaimopsis (14\%). The nematode genera Desmodora (20\%) and Marylynia $(16 \%)$ dominated the community at GC $1 \mathrm{~b}$ and the nematode genus Daptonema showed the highest relative abundance at GC $2 \mathrm{~b}(35 \%)$. These nematode genera have been found in all 4 samples. GC 2a was the only sample where a copepod genus (Dactylopodopsis, $10 \%$ ) showed the highest relative abundance. This genus was found at both GC1 and GC2 locations, but not in all samples. Like in GC 1b, the nematode Desmodora showed the highest relative abundance in AT 1 (33\%). This genus was also found in high percentage in all other AT samples. The copepod Amphiascella (that occurred in lower abundance in GC samples) was the most abundant genus in the AT 2 and AT 3 samples (15 and 8\%, respectively), but showed a relative abundance below $1 \%$ at AT 1.

\section{Community patterns}

The hierarchical cluster diagram based on group average linking grouped the samples by site (Fig. 3). ANOSIM detected a significant difference between the 2 seep sites (Global $\mathrm{R}=0.981$; $\mathrm{p}=0.029$; number of permutations 35). The SIMPER analysis showed an average dissimilarity of $72 \%$ between the 2 seep sites. The AT samples showed a slightly lower average similarity (40\%) than the GC samples (44\%). GC 
Fig. 3. Hierarchical cluster diagram of group-average linking based on Bray-Curtis community similarity from the cold seep samples Green Canyon (GC) and Atwater Valley (AV) and the hot vent samples Tica (TC) and Riftia Field (RF)

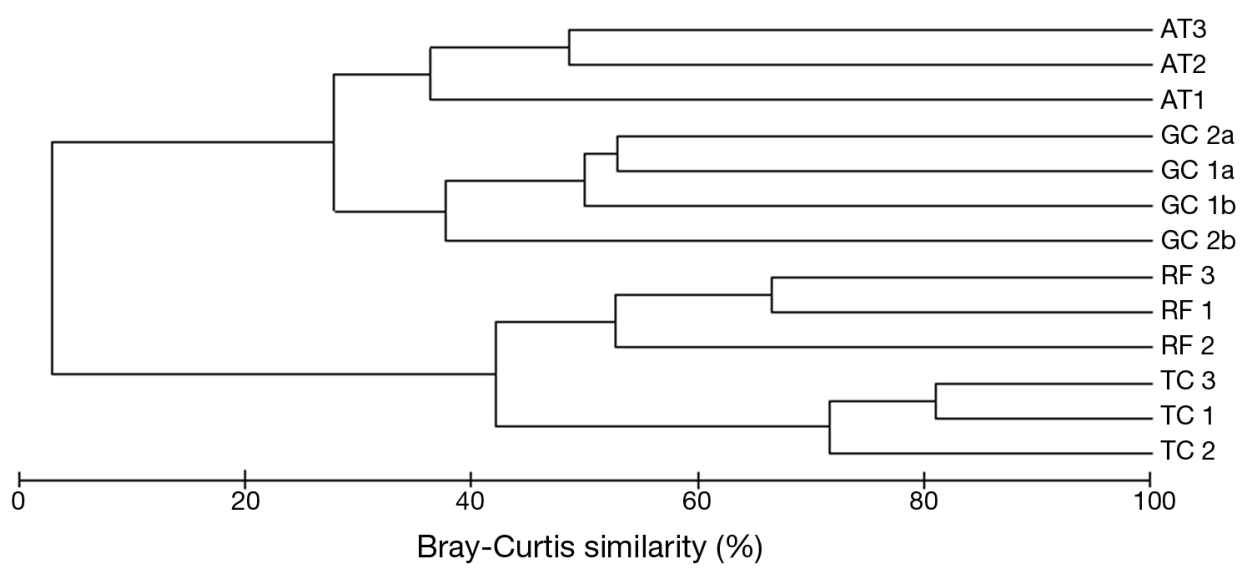

samples from location 1 and 2, only about $10 \mathrm{~km}$ apart, were not grouped according to these locations, but GC 1a and GC 2a were closer together than GC $1 \mathrm{~b}$ and GC $2 \mathrm{~b}$ samples, respectively (Fig. 3 ).

The data obtained from cold seeps above were compared with the data from a study of tubeworm associated meiobenthos from 2 hydrothermal vent sites: Tica (TC 1-3) and Riftia Field (RF 1-3) on the EPR region (Gollner et al. 2007). The total abundances in the vent samples ranged from 45 ind. (RF 1) to 29180 ind. (TC 2) and were not significantly different from the seep samples (Tables 1 \& 3). The abundances, standardized to an area of $10 \mathrm{~cm}^{2}$, ranged between $<1$ and 973 ind. $10 \mathrm{~cm}^{-2}$. Nematodes and copepods occurred in all vent samples, whereas ostracods were absent in the samples TC 1, RF 1, and RF 2. Nematodes were the most abundant taxon $\left(<1\right.$ to 946 ind. $\left.10 \mathrm{~cm}^{-2}\right)$, except in the samples with the lowest overall abundance RF 1 and RF 2, where copepods were most abundant (values $<1$ ind. $10 \mathrm{~cm}^{-2}$ ). The relative abundance ranged between 18 and $97 \%$ for nematodes and between 3 and $82 \%$ for copepods. The relative abundance between seeps and vents was not significantly different.
The vent communities included only 17 genera and were significantly lower than the total number of genera found in seep communities (bootstrapping, $\left.G_{\text {total, }} \mathrm{p}<0.001\right)$. The EG(n) was altogether low and ranged from 5 to 12 genera per sample, the number of expected genera EG(100) ranged from 4 to 9 (Table 2). Only 4 genera were shared between vents and both seep sites (the nematode genera Chromadorita and Daptonema and the copepod genera Halectinosoma and Xylora). Further, 4 genera were shared between the vent sites and the deeper seep sites at AT (the nematode genera Halomonhystera and Thalassomonhystera and the ostracod genera Thomontocypris and Xylocythere). The vent communities included 9 genera that were not found at any of the seep sites (8 copepod genera, 1 ostracod genus). No genera were shared between vents and the shallower GC seep site. The $J^{\prime}$ values ranged from 0.47 to 0.89 at vents and were not significantly different from values calculated for the seep samples (Tables 2 $\& 3)$. The $k$-dominance curves show that the vent communities were far less evenly distributed than the seep communities (Fig. 2). The $H^{\prime}$ values were significantly lower at vents $(0.37$ to 1.75$)$ than at the seep sites (bootstrapping, $\mathrm{p}<0.001$ ) (Table 3 ).

Table 3. Bootstrapping (p) for tube surface area standardized to $10 \mathrm{~cm}^{2}$ sample area, total abundance and abundance of nematodes and copepods standardized to $10 \mathrm{~cm}^{2}$ sample area, genus richness $(G)$, Shannon diversity $\left(H^{\prime}\right)$, Pielou's evenness $\left(J^{\prime}\right)$, as well as the Global R and p value of ANOSIM for the comparison of the 2 seep sites Green Canyon (GC) and Atwater Valley (AT) and the comparison of these seep sites with the vent sites Tica (TC) and Riftia Field (RF)

\begin{tabular}{|c|c|c|c|c|c|c|c|c|c|}
\hline \multirow{2}{*}{\multicolumn{2}{|c|}{$\begin{array}{c}\mathrm{p} \\
\text { (tube surface } \\
\text { area } 10 \mathrm{~cm}^{-2} \text { ) }\end{array}$}} & \multicolumn{3}{|c|}{$-\mathrm{p}$ (abundance; ind. $10 \mathrm{~cm}^{-2}$ ) } & \multirow{2}{*}{$\underset{(G)}{\mathrm{p}}$} & \multirow{2}{*}{$\underset{\left(H^{\prime}\right)}{\mathrm{p}}$} & \multirow{2}{*}{$\underset{\left(J^{\prime}\right)}{\mathrm{p}}$} & \multirow{2}{*}{$\begin{array}{c}\text { Dissimilarity } \\
(\%) \\
\text { Global R }\end{array}$} & \multirow{2}{*}{$\begin{array}{c}\mathrm{p} \\
\text { (ANOSIM) }\end{array}$} \\
\hline & & Total & Nematoda & Copepoda & & & & & \\
\hline Seeps (GC, AT) & $<0.001$ & 0.19 & 0.19 & 0.21 & 0.14 & 0.57 & 0.98 & 0.981 & 0.029 \\
\hline $\begin{array}{l}\text { Seeps - vents } \\
(\mathrm{GC}, \mathrm{AT}-\mathrm{TC}, \mathrm{RF})\end{array}$ & $<0.001$ & 0.23 & 0.11 & 0.03 & $<0.001$ & $<0.001$ & 0.13 & 1 & 0.002 \\
\hline
\end{tabular}


The nematode genus Thalassomonhystera had the highest relative abundance in the vent samples TC1RF 1 (27 to $91 \%$ ) and, therefore, contributed to the low evenness. The most abundant genus of RF 3 was the nematode Halomonhystera (55\%) and the sample RF 2 was dominated by the copepod genus Benthoxynus (51\%), which was not present in any of the seep samples. The nematodes Thalassomonhystera and Halomonhystera also occurred in lower abundances at AT seep samples, but were absent in GC samples.

The SIMPER analysis showed an average dissimilarity between communities of seeps and vents of $97.1 \%$. The vent group had an average similarity of $52 \%$, whereas the seep group showed only $34 \%$ average similarity. The nematode genera Thalassomonhystera and Halomonhystera contributed on average most to the similarity within the vent sites (33 and 29\%, respectively). The hierarchical cluster diagram based group average linking of Bray-Curtis similarity values clearly grouped the vent sites together and the seep sites together (Fig. 3). ANOSIM showed a significant difference between the communities of the vent and seep sites (Global $\mathrm{R}=1 ; \mathrm{p}=$ 0.002 ; number of permutations 999) and the MDS plot (not shown) based on Bray-Curtis similarities (2D Stress 0.01) shows 2 very tight and distinct groups that clearly separate vents and seeps.

\section{Abiotic factors and community characteristics}

The total meiobenthic abundance did not correlate significantly with the abiotic factors max. temperature $(\mathrm{r}=0.34 ; \mathrm{p}=0.257)$, max. sulfide concentration $(\mathrm{r}=0.22 ; \mathrm{p}=0.472)$, and $\min . \mathrm{pH}(\mathrm{r}=0.47 ; \mathrm{p}=0.106)$ (Fig. 4). In contrast, the EG(n) was negatively correlated with max. temperature $(\mathrm{r}=0.92 ; \mathrm{p}<0.001)$, max. sulfide concentration $(\mathrm{r}=0.89 ; \mathrm{p}<0.001)$, and was positively correlated with min. $\mathrm{pH}$ value $(\mathrm{r}=$ $0.71 ; \mathrm{p}<0.001$ ) (Fig. 4). The results of the Bio-ENV procedure indicate that these abiotic factors explain the community patterns to a high degree with rank correlations over 0.75 .

The seep aggregations from the upper slope showed a mean meiofauna abundance of more than 300 ind. per $10 \mathrm{~cm}^{2}$ tube surface area, the aggregations from the lower slope around 30 ind. per $10 \mathrm{~cm}^{2}$ tube surface area and in the Riftia aggregations from the hot vent sites only $\sim 1$ meiofauna ind. per $10 \mathrm{~cm}^{2}$ tube surface area was found. The relationship of tubeworm surface to sample area showed that the Riftia pachyptila aggregations at the vent sites were $\sim 22$ times more structured than the tubeworm aggre- gations formed by Lamellibrachia luymesi, Seepiophila jonesi, and Escarpia laminata from the seeps (Cordes et al. 2005b, Govenar et al. 2005).

\section{DISCUSSION}

Long-term stability, longevity of tubeworms, amelioration of potentially stressful abiotic factors by tubeworms for their associated animals, and in situ chemosynthetic primary production are features that make the hydrocarbon seeps in the Gulf of Mexico a benign and resource rich habitat. According to general ecological theory, diversity is expected to be high in such undisturbed, relatively stressless, and productive environments (Hacker \& Gaines 1997, Sousa 2001, Scrosati \& Heaven 2007). Consistent with these predictions, our study shows that the epizooic, meiobenthic community is indeed diverse. Although the associated meiofauna at the shallow GC and deep AT seep sites is composed of the same major taxa and exhibits similar univariate measures of diversity, the sites differ in terms of genus composition. Epizooic meiobenthos associated with tubeworms occur at both cold seeps and hydrothermal vents, but despite their similar chemosynthetic foundation species and the rather low, similar abundances, we found no further similarities between these communities. The metazoan meiofauna from the more extreme hydrothermal vent sites is composed of only half the major taxa found at seeps and is also far less diverse in terms of EG(n), probably due to the differing environments and stress regimes. The few genera found at both environments are comprised of cosmopolitans as well as deep-sea genera, but no specific genera restricted to chemosynthesis-based ecosystems.

\section{Low abundance at seeps}

We found similar and rather low meiofauna abundances at both seep sites from different depths. Although a general decreasing trend in abundance as productivity declines with depth is reported worldwide in the deep sea (Soltwedel 2000, Carney 2005, Giere 2009), we did not find any significant differences between the sites from the upper and lower slope. This was also as expected, owing to in situ primary production and the independence of organisms from organic influx from the upper layers production. The food supply of organisms living in chemosynthetic symbioses does not decrease with depth as does the background fauna (Carney 2005, Cordes 2007), and 
therefore abundance of associated heterotrophs should be accordingly independent (Carney 2005).

The low meiofauna abundances were surprising, since the highly productive seep systems are, in general, known to support an abundant associated macrofaunal community. Whereas the highly productive system of early successional tubeworm stages is capable of supporting a highly abundant associated macrofaunal community, the abundance of associated species declines with decreasing sulfide concentrations in the older aggregations (Bergquist et al. 2003b, Cordes et al. 2005b, 2006). In our study of mid-successional stages, one would thus expect
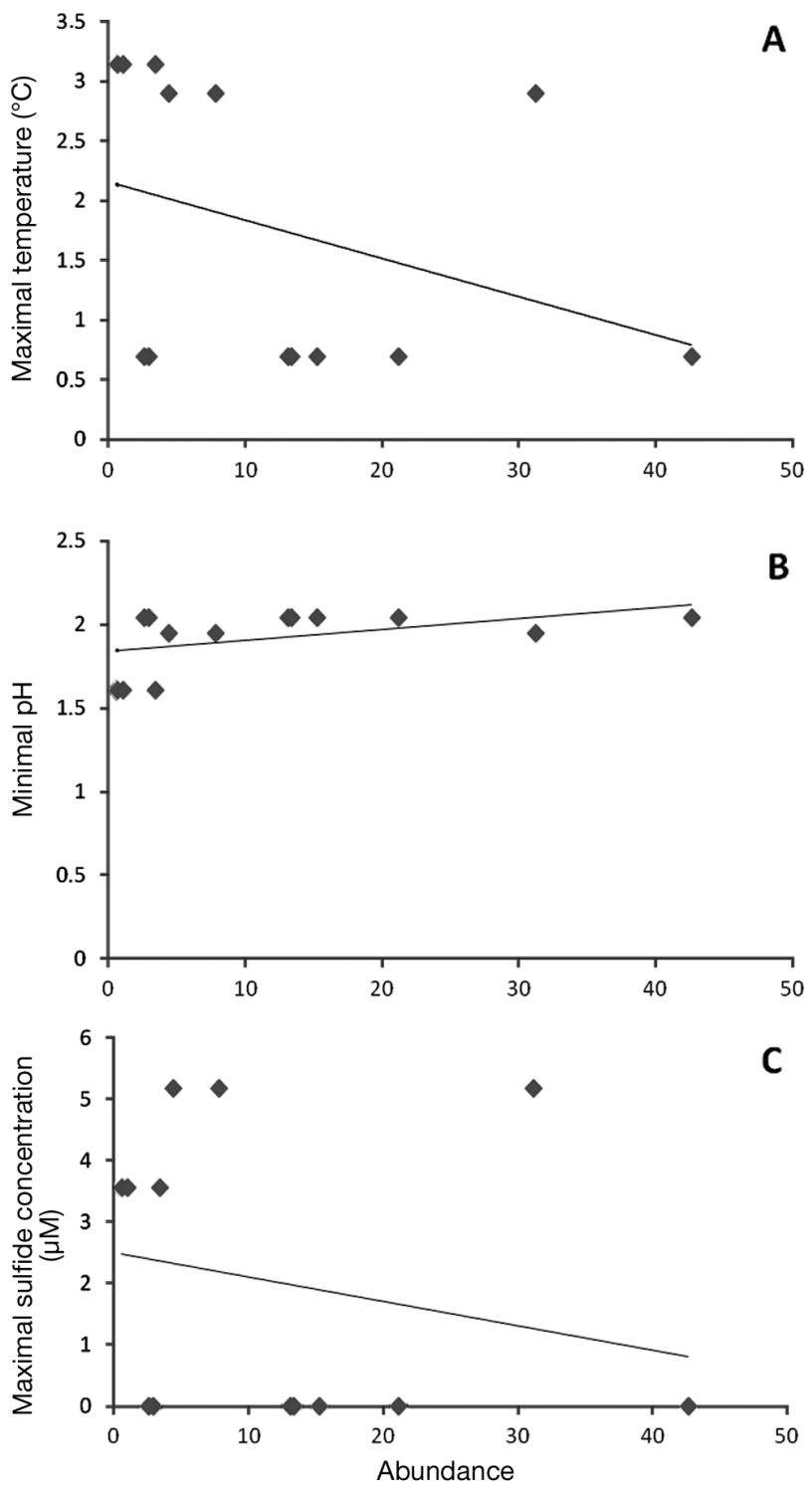

high or intermediate meiofauna abundances. Competition may determine the low abundances observed, as different macrofauna genera are temporarily in the same size class as meiofauna, during their larval development, and could compete for the same resources. In addition, top-down control via predation could shape meiofaunal abundance. Meiofauna are preyed upon by other meiofauna genera and macrofauna (Giere 2009), as indicated by 2 recent studies of seep infauna, which found an inverse correlation between macrofauna and meiofauna/nematode densities (Debenham et al. 2004, Van Gaever et al. 2009b).
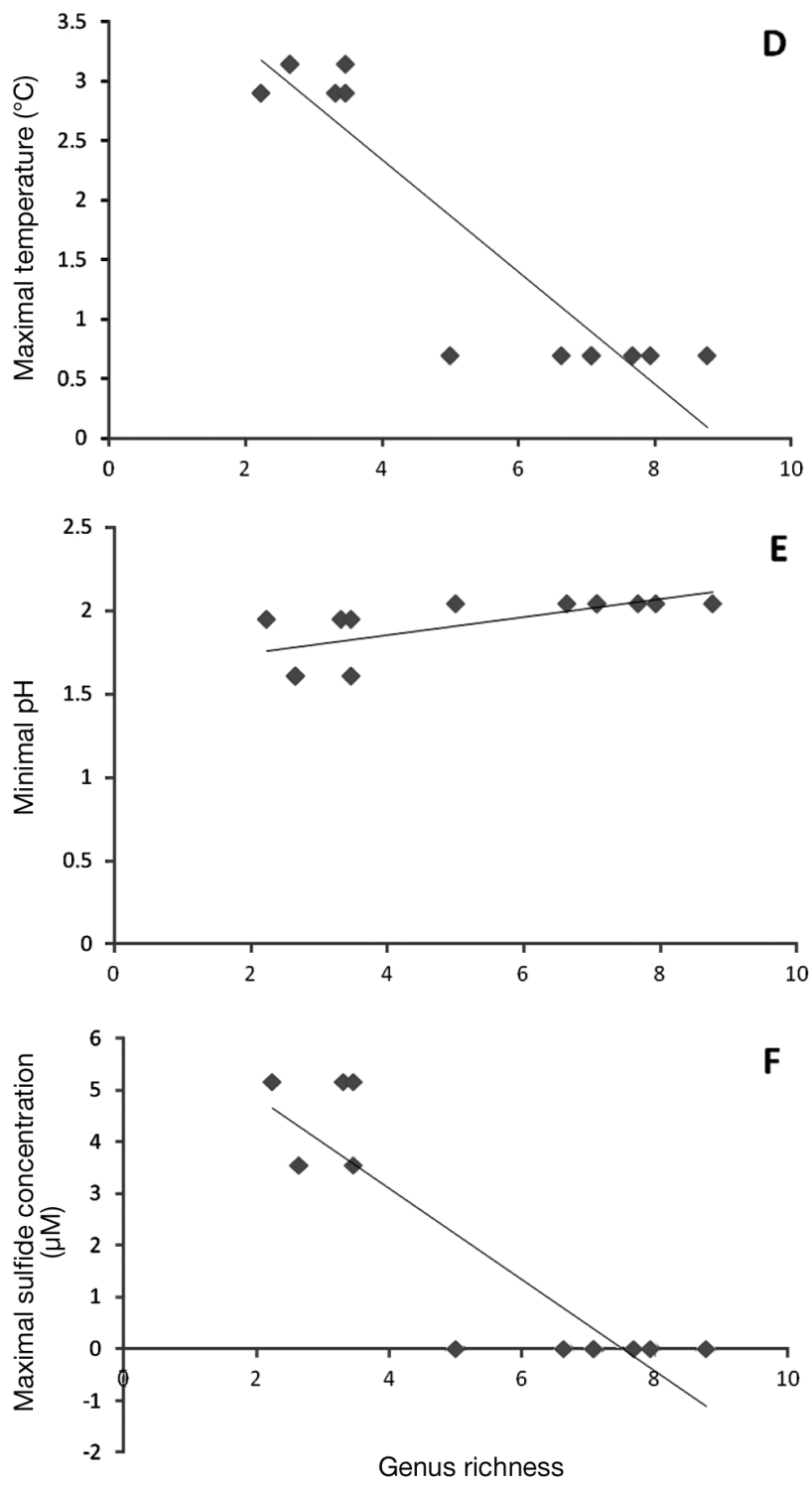

Fig. 4. Tests for significance of correlations among abundance and the abiotic factors max. temperature (A), min. pH (B), and max. sulfide concentration (C), as well as genus richness and the abiotic factors max. temperature (D), min. $\mathrm{pH}(\mathrm{E})$ and max. sulfide concentration (F) using Pearson's r ( $F$-value and $t$-value calculations by STATISTICA). A, B, C not significant; D, E, F significant (see text for $\mathrm{r}$ and $\mathrm{p}$ values) 


\section{High diversity at seeps}

Physiological stress - such as that caused by toxic cold seep fluids - is one of the major factors shaping diversity, with highest diversity expected at intermediate stress levels (Sousa 2001, Scrosati \& Heaven 2007). Seeping processes in the Gulf of Mexico are constant and are characterized by flows of reduced chemicals in relatively high concentrations, as well as occasional fluid and gas expulsions (Levin 2005). In some areas, considerable amounts of biogenic sulfide, that is toxic to animals (Bagarinao 1992), in conjunction with low oxygen concentrations, create extreme environments (Levin 2005). However, overall environmental conditions among tubeworms in mid-successional stages are quite different. Such aggregations, e.g. those studied at GC on the upper slope, were composed of up to 1500 ind. of Lamellibrachia luymesi and Seepiophila jonesi (Cordes et al. 2005b). These aggregations of vestimentiferans have a high demand of reduced sulfur species for energy generation used for carbon fixation (Cordes et al. 2005b). Tube worms take up considerable amounts of sulfide contained in the sediment (and seeping into the water column) (Cordes et al. 2009), resulting in very low or undetectable sulfide concentrations and ambient deep-sea oxygen levels. Above the sediment, sulfide concentrations in the water around tubeworm aggregations similar in size structure to those we studied are very low $(<1 \mu \mathrm{M})$, rarely exceeding $4 \mu \mathrm{M}$, while almost no sulfide is detectable around the plumes of the tubeworms (Bergquist et al. 2003b, Cordes et al. 2009). Thus, environmental stress through seepage is low in the observed tubeworm aggregations for the epizooic meiofauna, and may not have negative influence on meiofauna diversity. Consistent with these benign conditions, we found a diverse and evenly distributed community.

In addition to amelioration of environmental conditions, the tubeworms considerably increase the habitat in size by providing large surfaces of tubes for colonization of associated animals. Although the tubeworm aggregations we studied were composed of different vestimentiferan species, the shallow GC sites of Lamellibrachia luymesi and Seepiophila jonesi and the deeper AT sites of Escarpia laminata and Lamellibrachia ssp., both showed a similar degree of surface increase of between 2.3 and 4.5. Furthermore, the 3-dimensional structure of tubeworms increases habitat complexity (Bergquist et al. 2003a, Cordes et al. 2005b, 2010), and both factors are expected to facilitate and increase diversity in general (Bruno \& Bertness 2001).
Ecological theory predicts a unimodal relationship between diversity and productivity (Huston 1994). Our results for the epizooic meiofauna are in accordance with this prediction, since we found high meiofauna diversity at an intermediate productivity level. In situ primary production by free-living bacteria and by foundation species such as vestimentiferans living in symbiosis with chemoautotrophic sulfide-oxidizing bacteria (Childress \& Fisher 1992, Fisher et al. 1997) is much higher than productivity of the surrounding deep sea, even comparable to the most productive photic marine systems (Sarrazin \& Juniper 1999). Following succession studies of tubeworm aggregations from the upper slope, the earliest successional stages are characterized by active seepage and enhanced chemoautotrophic production, which decline in middle and finally cease in the latest successional stages (Bergquist et al. 2002, Cordes et al. 2005b, 2006). The macrofauna communities associated with tubeworms indeed appear to follow the unimodal productivity pattern, as in early successional stages communities with very low species diversity are found, while the highest diversity levels develop in mid-successional stages (Cordes et al. 2005b). Interestingly, meiofauna diversity is higher $\left(\mathrm{H}^{\prime} \mathrm{GC} 2.77 \pm 0.47\right.$, AT $\left.2.99 \pm 0.61\right)$ than macrofauna diversity ( $\mathrm{H}^{\prime} \mathrm{GC} 2.23 \pm 0.54$, AT $\left.1.08 \pm 0.46\right)$ in similarly productive stages when comparing the same aggregations (Cordes et al. 2005b, 2010).

\section{Different meiofaunal composition at different depths}

Our results support studies of cold seep macrofauna that emphasize a bathymetric zone of transition around $1000 \mathrm{~m}$ (Carney 2005, Cordes et al. 2010) as has been reported for adjacent deep sea sediments (Pequegnat et al. 1990). Despite a depth difference of $1600 \mathrm{~m}$ between the seepage sites at Green Canyon and Atwater Valley, the associated meiofauna communities were similar in univariate measures of diversity and abundance. This is in contrast to associated macrofauna communities, which show highest diversities at 500-600 $\mathrm{m}$ depth (Bergquist et al. 2003b, Cordes et al. 2005b, 2006, 2010). While some meiofauna studies from other seas report a decrease in abundance and diversity with depth related losses of particulate organic matter (POM), other studies document exactly the opposite-an inverse relationship between POM flux and meiofauna diversity (Giere 2009 [p. 290] and references therein). Several studies of both macro- and (nematode) meiofauna propose a mid-slope diversity maximum (Pequegnat 
et al. 1990, Giere 2009, Cordes et al. 2010). But considering that these studies focused on meiobenthos from deep-sea sediments and not on epizooic meiofauna from chemosynthetic ecosystems, comparisons should be drawn carefully. However, the multivariate community analyses of the 2 cold seep sites not only showed that within-site similarities were relatively low (GC $44 \%$ and AT 40\% SIMPER similarity), but also that between-site dissimilarity was high (SIMPER dissimilarity $72 \%$ ). In addition, the 2 sites shared only about half of the genera (53 genera) from 5 higher taxa, whereas kinoryhnchs and isopods occurred in low numbers only in AT samples from the lower slope. The other half of genera was found exclusively on the GC upper slope (42 genera) and on the AT deeper site (57 genera). Although the majority of the surveyed meiofauna genera are cosmopolitan and found in several marine ecosystems, some genera - including the nematode genus Thalassomonhystera, the ostracod genus Xylocythere or the genera belonging to the copopod family Argestidae (e.g. Argestes, Mesocletodes and Fultonia) — are reported as typical deep-sea inhabitants, and were present only on the lower slope accordingly (George 2004, Maddocks 2005, Vanreusel et al. 2010b).

The present study was carried out at genus level only, and thus, as most genera include cosmopolitans as well as specialists, e.g. from the deep sea, clear evidence for bathymetric trends cannot be given with this study. For tubeworm-associated macrofauna, it was found that communities were significantly different at the species level among depth ranges, whereas no significant difference was discovered among communities separated by geographic distance in the Gulf of Mexico (Cordes et al. 2010). We assume that this could be valid as well for the meiofauna communities, though community studies at species level from similar depths, but separated by distance, have to be conducted to affirm this assumption.

\section{Contrasting diversity at seeps and vents}

Although both seep and vent ecosystems are based on chemosynthetic in situ primary production (Childress \& Fisher 1992, Levin 2005) and harbor vestimentiferan foundation species (Bright \& Lallier 2010), they exhibit fundamentally different disturbance and stress regimes. As a result of the different environmental conditions and the consequent differences in life-history patterns for the foundation species, the associated meiobenthic communities are strikingly different in terms of EG(n) and commu- nity composition, exhibiting high seep but low vent diversity.

The stability-time hypothesis suggests an increase in diversity with time (Sanders 1968). In contrast to the stable and long-lived cold seeps, hydrothermal vents are highly unstable, short-lived environments with a life span confined by large-scale disturbances such as catastrophic volcanic eruptions and tectonic events, and small-scale disturbances when vent flow ceases. The vent sites Tica and Riftia Field on the East Pacific Rise (EPR) $9^{\circ} 50^{\prime} \mathrm{N}$ region (Gollner et al. 2007) were struck by volcanic eruptions in 1991 and 2006 (Shank et al. 1998, Tolstoy et al. 2006). In both events, most of the communities were destroyed and some newly formed vents were colonized rapidly by the tubeworm Tevnia jerichonana (Shank et al. 1998, M. Bright pers. obs.). Within 32 mo post 1991 eruption, Riftia pachypitla replaced the primary colonist (Shank et al. 1998). Since the observed vent tubeworm aggregations were sampled in 2001 and 2002, they were younger than $\sim 7 \mathrm{yr}$, which is in stark contrast to the seep tubeworm aggregation which are estimated to be 20 to $40 \mathrm{yr}$ old (Cordes et al. 2005b). In addition, $R$. pachyptila is extremely fast growing $\left(>85 \mathrm{~cm} \mathrm{yr}^{-1}\right)$ and short-lived (Bright \& Lallier 2010), whilst the estimated age of slow growing seep tubeworms is much longer, between 20 and 150 yr (Cordes et al. 2005b). These different time and stability factors might explain the contrasting diversity patterns within seep and vent tubeworm aggregations.

The hydrothermal vent tubeworms themselves and their associated communities are exposed to high stress levels induced by extreme and fluctuating physico-chemical conditions comprising relatively high temperature and low $\mathrm{pH}$ gradients, high sulfide and low oxygen concentrations as well as rapid changes in vent fluid composition. As already pointed out by Gollner et al. (2010a), these factors may be the driving forces behind the low meiofauna diversity at vent tubeworm aggregations and hydrothermal vents in general. Compared to the moderate environmental conditions and high diversity of meiofauna from tubeworm aggregations at cold seeps, it is not surprising that EG(n) was correlated with the abiotic factors $T_{\max }$ max. sulfide concentration, and min. $\mathrm{pH}$ value. Also, the results of the Bio-ENV procedure indicate that these abiotic factors explain the community patterns to a high degree. The low EG(n) at vents might point out that a few meiofauna genera are able to tolerate the extreme conditions in this habitat, whereas high EG(n) at seeps might indicate conditions favoring a much larger number of genera. 


\section{Different colonization potential of seeps and vents}

Another factor, besides the stable and benign environmental conditions, explaining the higher diversity at seeps might be the different geological settings of the 2 study sites. The hydrothermal vent sites are located on mid ocean ridges, surrounded by hard basalt substrate and relatively far from deepsea plains, whereas the cold seep sites are found in the midst of the soft sediments of the Gulf of Mexico deep-sea plains, which are known to harbor a highly diverse and abundant infauna (Levin et al. 2001, Baguley et al. 2006, Bright et al. 2010). This vicinity to the species rich deep-sea plains could allow more genera to colonize seep tubeworm aggregations. For example, the nematode genus Desmodora that we found in high abundances epizooically on tubes, was also found to be dominant in seep sediments (Van Gaever et al. 2009b). In general, this genus is present in deep-sea sediments, albeit in low abundances (Soetaert \& Heip 1995, Vanreusel et al. 2010b). In contrast, the Riftia aggregations from hot vents are spatially further away from these highly diverse sedimented areas and surrounded by the bare basalt of the rocky axial summit collapse trough. This environment harbors a less diverse community compared to the deep-sea plains. Thus, at vents the potential genus poolincluding genera that might be capable of living epibenthically, crossing the bare basalt area and then adapting to the harsh conditions within vent tubeworm aggregations - may be smaller (Gollner et al. 2010a, Vanreusel et al. 2010b).

\section{Occurrence of seep and vent genera in other ecosystems}

Our study on meiofauna from seeps, as well as other studies from vents and seeps (Van Gaever et al. 2009a, Gollner et al. 2010a, Vanreusel et al. 2010b), revealed no genera typical for chemosynthesis-based environments. This is in stark contrast to the macrofauna where a large proportion of genera is - at least at seeps in early successional stages-endemic to these chemosynthetic environments (Tunnicliffe et al. 1998, Bergquist et al. 2003b, Cordes et al. 2006). All identified meiofauna seep genera from this study were already known to science, and only very few genera (with few individuals) were undescribed. However, this might not be due to their restricted occurrence at seeps only, but to the undersampled deep-sea habitat in general. Underlying reasons for these profound differences in meio- and macrofauna patterns are not known yet.

Eight meiofauna genera were co-occurring in tubeworm aggregations at hot vents and cold seeps, and all of them are also known from non-chemosynthesis-based environments. Six of them (the 2 harpacticoids Halectinosoma and Xylora, the ostracod Thomontocypris and the 3 nematode genera Chromadorita, Daptonema, and Halomonhystera) are cosmopolitan and were found in deep- and shallowwater environments (Heip et al. 1985, Hicks 1988, Maddocks 2005, Clément \& Moore 2007). The remaining 2 genera, the ostracod genera Xylocythere and the nematode genera Thalassomonhystera, were mainly reported from the deep sea (Vanreusel et al. 2010a,b and references therein). Nine genera were found at vents and not at seeps, but are mostly known from other environments. Six belong to the copepod family Dirivultidae, a family restricted to deep-sea hydrothermal vent habitats and the surrounding axial summit trough (Gollner et al. 2010b). Dirivultidae can strongly dominate vent communities (Gollner et al. 2010a), and their absence at seeps contributes highly to the dissimilarity between vents and seeps. The 2 remaining copepod genera belong to the order Harpacticoida, whereas the genus Bathylaophonte has so far only been described from hydrothermal vents (Lee \& Huys 1999), and the other one is as yet unidentified. The ostracod genus Polycopetta was exclusively found at the vent site Riftia Field, but at none of the seep sites. This genus was recorded before in shallow depths in the vicinity of Japan and in Antarctica (see Kornicker \& Harrison-Nelson 2005).

\section{CONCLUSIONS}

Our results show that tubeworm associated meiobenthos from 2 different cold seep sites shows similar low abundances and relatively high and similar diversities of higher taxa and at the genus level. The community composition at the genus level, however, is rather heterogenous. Whether this is due to biogeographic patterns in the Gulf of Mexico or a depth gradient is not known yet. In contrast, epizooic communities associated with tubeworms from hydrothermal vents, are strikingly different to those at seeps. They are composed of a rather limited number of higher taxa and are also far less diverse at the genus level. While only a few genera are adapted to the extreme and unstable environmental conditions at hydrothermal vents, a far more diverse and evenly distributed meiofauna community thrives at a moder- 
ate and far more stable cold seep environment. Although a few genera were found inhabiting both chemosynthesis-based ecosystems, tubeworm associated communities at vents harbor some specialist genera, which have not been found at seeps.

Acknowledgements. This work was supported financially by the Austrian Science Foundation Grants FWF (P16774-B03 and P20190-B17 to M.B.) and the Mineral Management Service Contract \#1435-01-05-39187 to TDI-Brooks International. We thank the captains and crews of the RV 'Seward Johnson II' and the NOAA RV 'Ronald Brown' and the pilots of the DSV 'Johnson Sea-Link I and II' and ROV 'Jason'. We especially thank C. Fisher for the scientific cooperation and B. Pflugfelder for processing the meiofauna samples on the 2003 cruise to the Gulf of Mexico. Thanks to M. Raes and $\mathrm{J}$. Ingels for training in nematode taxonomy. We also thank the taxonomists L. Kornicker and R. Maddocks for the identification of ostracods, K. Larsen for identifying tanaids and I. Bartsch for the identification of halacarids.

\section{LITERATURE CITED}

Bagarinao T (1992) Sulfide as an environmental factor and toxicant: tolerance and adaptations in aquatic organisms. Aquat Toxicol 24:21-62

Baguley JG, Montagna PA, Hyde LJ, Kalke RD, Rowe GT (2006) Metazoan meiofauna abundance in relation to environmental variables in the northern Gulf of Mexico deep sea. Deep-Sea Res I 53:1344-1362

Bergquist DC, Williams FM, Fisher CR (2000) Longevity record for deep-sea invertebrate - the growth rate of a marine tubeworm is tailored to different environments. Nature 403:499-500

> Bergquist DC, Urcuyo IA, Fisher CR (2002) Establishment and persistence of seep vestimentiferan aggregations on the upper Louisiana slope of the Gulf of Mexico. Mar Ecol Prog Ser 241:89-98

> Bergquist DC, Andras JP, McNelis T, Howlett S, van Horn MJ, Fisher CR (2003a) Succession in Gulf of Mexico cold seep vestimentiferan aggregations: the importance of spatial variability. PSZN I: Mar Ecol 24:31-44

Bergquist DC, Ward T, Cordes EE, McNelis T and others (2003b) Community structure of vestimentiferan-generated habitat islands from Gulf of Mexico cold seeps. J Exp Mar Biol Ecol 289:197-222

Bray JR, Curtis JT (1957) An ordination of the upland forest communities of southern Wisconsin. Ecol Monogr 27: 325-349

Bright M, Lallier FH (2010) The biology of vestimentiferan tubeworms. Oceanogr Mar Biol Annu Rev 48:213-266

Bright M, Plum C, Riavitz LA, Nikolov N, Martinez Arbizu P, Cordes EE, Gollner S (2010) Epizooic metazoan meiobenthos associated with tubeworm and mussel aggregations from cold seeps of the northern Gulf of Mexico. Deep-Sea Res II 57:1982-1989

Bruno JF, Bertness MD (2001) Habitat modification and facilitation in benthic marine communities. In: Marine Community Ecology. Sinauer Associates, Sunderland, MA, p 201-218

Bruno JF, Stachowicz JJ, Bertness MD (2003) Inclusion of facilitation into ecological theory. Trends Ecol Evol 18: $119-125$
Carney RS (2005) Zonation of deep biota on continental margins. Oceanogr Mar Biol Annu Rev 43:211-279

Childress JJ, Fisher CR (1992) The biology of hydrothermal vent animals - physiology, biochemistry and autotrophic symbioses. Oceanogr Mar Biol Annu Rev 30:337-441

Clarke KR, Gorley RN (2006) PRIMER v6: user manual/ tutorial. PRIMER-E, Plymouth

Clément M, Moore CG (2007) Towards a revision of the genus Halectinosoma (Copepoda, Harpacticoida, Ectinosomatidae): new species from the North Atlantic and Arctic regions. Zool J Linn Soc 149:453-475

Cordes EE, Arthur MA, Shea K, Arvidson RS, Fisher CR (2005a) Modeling the mutualistic interactions between tubeworms and microbial consortia. PLoS Biol 3:497-506

> Cordes EE, Hourdez S, Predmore BL, Redding ML, Fisher CR (2005b) Succession of hydrocarbon seep communities associated with the long-lived foundation species Lamellibrachia luymesi. Mar Ecol Prog Ser 305:17-29

Cordes EE, Bergquist DC, Predmore BL, Jones C, Deines P, Telesnicki G, Fisher CR (2006) Alternate unstable states: convergent paths of succession in hydrocarbon-seep tubeworm-associated communities. J Exp Mar Biol Ecol 339:159-176

> Cordes EE, Bergquist DC, Redding ML, Fisher CR (2007) Patterns of growth in cold-seep vestimenferans including Seepiophila jonesi: a second species of long-lived tubeworm. Mar Ecol 28:160-168

Cordes EE, Bergquist DC, Fisher CR (2009) Macro-ecology of Gulf of Mexico cold seeps. Annu Rev Mar Sci 1: 143-168

> Cordes EE, Becker EL, Hourdez S, Fisher CR (2010) Influence of foundation species, depth, and location on diversity and community composition at Gulf of Mexico lowerslope cold seeps. Deep-Sea Res II 57:1870-1881

Dayton PK (1972) Toward an understanding of community resilience and the potential effects of enrichments to the benthos at McMurdo Sound, Antarctica. In: Parker BC (ed) Proceedings of the colloquium on conservation problems in Antarctica. Allen Press, Lawrence, KS, p 81-96

> Debenham NJ, Lambshead PJD, Ferrero TJ, Smith CR (2004) The impact of whale falls on nematode abundance in the deep sea. Deep-Sea Res I 51:701-706

Fisher CR, Urcuyo IA, Simpkins MA, Nix E (1997) Life in the slow lane: growth and longevity of cold-seep vestimentiferans. PSZN I: Mar Ecol 18:83-94

Fisher C, Roberts H, Cordes E, Bernard B (2007) Cold seeps and associated communities of the Gulf of Mexico. Oceanography 20:118-129

> Freytag JK, Girguis PR, Bergquist DC, Andras JP, Childress JJ, Fisher CR (2001) A paradox resolved: sulfide acquisition by roots of seep tubeworms sustains net chemoautotrophy. Proc Natl Acad Sci USA 98:13408-13413

George KH (2004) Description of two new species of Bodinia, a new genus incertae sedis in Argestidae Por, 1986 (Copepoda, Harpacticoida), with reflections on argestid colonization of the Great Meteor Seamount plateau. Org Divers Evol 4:241-264

Giere O (2009) Meiobenthology. The microscopic motile fauna of aquatic sediments, 2nd edn. Springer Verlag, Berlin

Gollner S, Zekely J, Govenar B, Le Bris N, Nemeschkal HL, Fisher CR, Bright M (2007) Tubeworm-associated permanent meiobenthic communities from two chemically different hydrothermal vent sites on the East Pacific Rise. Mar Ecol Prog Ser 337:39-49

Gollner S, Riemer B, Martinez Arbizu P, Le Bris N, Bright M (2010a) Diversity of meiofauna from the $9^{\circ} 50^{\prime} \mathrm{N}$ East 
Pacific Rise across a gradient of hydrothermal fluid emissions. PLoS ONE 5:e12321

Gollner S, Ivanenko VN, Arbizu PM, Bright M (2010b) Advances in taxonomy, ecology, and biogeography of dirivultidae (copepoda) associated with chemosynthetic environments in the deep sea. PLoS ONE 5:e9801

> Govenar B, Le Bris N, Gollner S, Glanville J, Aperghis AB, Hourdez S, Fisher CR (2005) Epifaunal community structure associated with Riftia pachyptila aggregations in chemically different hydrothermal vent habitats. Mar Ecol Prog Ser 305:67-77

Graham MH (2004) Effects of local deforestation on the diversity and structure of southern California giant kelp forest food webs. Ecosystems 7:341-357

$>$ Hacker SD, Gaines SD (1997) Some implications of direct positive interactions for community species diversity. Ecology 78:1990-2003

Heip C, Vincx M, Vranken G (1985) The ecology of marine nematodes. Oceanogr Mar Biol Annu Rev 23:399-489

> Hicks G (1988) Systematics of the Donsiellinae Lang (Copepoda, Harpacticoida). J Nat Hist 22:639-684

Higgins RP, Thiel H (1988) Introduction to the study of meiofauna. Smithsonian Institution Press, Washington, DC

Huston MA (1994) Biological diversity: the coexistence of species on changing landscapes. Cambridge University Press, Cambridge

Kornicker LS, Harrison-Nelson E (2005) Ostracoda from Johnston Atoll, Pacific Ocean, and proposal of a new tribe, Bruuniellini (Myodocopina: Cylindroleberididae). Pac Sci 59:323-362

Le Bris N, Govenar B, Le Gall C, Fisher CR (2006) Variability of physico-chemical conditions in $9^{\circ} 50^{\prime} \mathrm{N}$ EPR diffuse flow vent habitats. Mar Chem 98:167-182

Lee W, Huys R (1999) Bathylaophonte gen. nov. from deepsea hydrothermal vents and the polyphyly of Paronychocamptus (Copepoda: Harpacticoida). Cah Biol Mar 40:293-328

Levin LA (2005) Ecology of cold seep sediments: interactions of fauna with flow, chemistry and microbes. Oceanogr Mar Biol Annu Rev 43:1-46

> Levin LA, Etter RJ, Rex MA, Gooday AJ and others (2001) Environmental influence on regional deep-sea species diversity. Annu Rev Ecol Syst 32:51-93

Lutz RA, Shank TM, Fornari DJ, Haymon RM, Lilley MD, Vondamm KL, Desbruyeres D (1994) Rapid growth at deep-sea vents. Nature 371:663-664

Maddocks RF (2005) Three new species of podocopid ostracoda from hydrothermal vent fields at $9^{\circ} 50^{\prime} \mathrm{N}$ on the East Pacific Rise. Micropaleontology 51:345-372

McIntyre AD, Warwick RM (1984) Meiofauna techniques. In: Holme NA, McIntyre, AD (eds) Methods for the study of marine meiobenthos. Blackwell Scientific Publications, Oxford, p 217-244

McMullin E (2003) Phylogeography of deep-sea vestimentiferans and a population genetics study of two species, Lamellibrachia luymesi and Seepiophila jonesi, from the Gulf of Mexico. PhD thesis, Pennsylvania State University, PA

Nemeschkal HL (1999) Morphometric correlation patterns of adult birds (Fringillidae: Passeriformes and Columbiformes) mirror the expression of developmental control genes. Evolution 53:899-918

Pequegnat WE, Gallaway BJ, Pequegnat LH (1990) Aspects of the ecology of the deep-water fauna of the Gulf of Mexico. Am Zool 30:45-64

Platt HM, Warwick RM (1983) Free-living marine nematodes. I. British enoplids. Synopses of the British fauna,
Vol 28. Cambridge University Press, Cambridge

Platt HM, Warwick RM (1988) Free-living marine nematodes. Part II. British Chromadorids. Synopses of the British fauna, Vol 38. Backhuys, Leiden

- Sanders HL (1968) Marine benthic diversity: a comparative study. Am Nat 102:243-282

Sarrazin J, Juniper SK (1999) Biological characteristics of a hydrothermal edifice mosaic community. Mar Ecol Prog Ser 185:1-19

Scrosati R, Heaven C (2007) Spatial trends in community richness, diversity, and evenness across rocky intertidal environmental stress gradients in eastern Canada. Mar Ecol Prog Ser 342:1-14

- Shank TM, Fornari DJ, Von Damm KL, Lilley MD, Haymon RM, Lutz RA (1998) Temporal and spatial patterns of biological community development at nascent deep-sea hydrothermal vents ( $9^{\circ} 50^{\prime} \mathrm{N}$, East Pacific Rise). DeepSea Res II 45:465-515

Singh R, Blattler WA, Collinson AR (1993) An amplified assay for thiols based on reactivation of papain. Anal Biochem 213:49-56

Soetaert K, Heip C (1995) Nematode assemblages of deepsea and shelf break sites in the North Atlantic and Mediterranean Sea. Mar Ecol Prog Ser 125:171-183

> Soltwedel T (2000) Metazoan meiobenthos along continental margins: a review. Prog Oceanogr 46:59-84

Sousa WP (2001) Natural disturbance and the dynamics of marine benthic communities. In: Bertness MD, Hay GM (eds) Marine community ecology. Sinauer, Sunderland, MA, p 85-130

Tolstoy M, Cowen JP, Baker ET, Fornari DJ and others (2006) A sea-floor spreading event captured by seismometers. Science 314:1920-1922

> Tunnicliffe V, McArthur AG, McHugh D (1998) A biogeographical perspective of the deep-sea hydrothermal vent fauna. Adv Mar Biol 34:353-442

Van Dover CL, Trask JL (2000) Diversity at deep-sea hydrothermal vent and intertidal mussel beds. Mar Ecol Prog Ser 195:169-178

Van Gaever S, Olu K, Derycke S, Vanreusel A (2009a) Metazoan meiofaunal communities at cold seeps along the Norwegian margin: influence of habitat heterogeneity and evidence for connection with shallow-water habitats. Deep-Sea Res I 56:772-785

> Van Gaever S, Galéron J, Sibuet M, Vanreusel A (2009b) Deep-sea habitat heterogeneity influence on meiofaunal communities in the Gulf of Guinea. Deep-Sea Res II 56: 2259-2269

- Van Gaever S, Raes M, Pasotti F, Vanreusel A (2010) Spatial scale and habitat-dependent diversity patterns in nematode communities in 3 seepage related sites along the Norwegian Sea margin. Mar Ecol 31:66-77

Vanreusel A, Fonseca G, Danovaro R, Da Silva MC and others (2010a) The contribution of deep-sea macrohabitat heterogeneity to global nematode diversity. Mar Ecol 31: 6-20

Vanreusel A, De Groote A, Gollner S, Bright M (2010b) Ecology and biogeography of free-living nematodes associated with chemosynthetic environments in the deep sea: a review. PLoS ONE 5:e12449

> Veit-Köhler G, Laudien J, Knott J, Velez J, Sahade R (2008) Meiobenthic colonisation of soft sediments in arctic glacial Kongsfjorden (Svalbard). J Exp Mar Biol Ecol 363: 58-65

Warwick RM, Platt HM, Somerfield PJ (1998) Free-living marine nematodes. III. Monhysterids. Synopsis of the British fauna, Vol 53. Field Studies Council, Shrewsbury 